\title{
Internal Morphology of Osteoderms of Extinct Armadillos and Its Relationship with Environmental Conditions
}

\author{
M. R. Ciancio ${ }^{1}$ - C. M. Krmpotic ${ }^{1}$ - A. C. Scarano ${ }^{1,2}$ - M. B. Epele ${ }^{3}$
}

(C) Springer Science+Business Media, LLC 2017

\begin{abstract}
The most complete and continuous fossil record of armadillos is composed mostly by isolated osteoderms, frequently found in paleontological and archaeological sites that bear continental South American mammals. Their external morphology has been used to define several species. In the last decade, many authors have focused on the internal structure of vertebrate osteoderms using histological and paleohistological studies. These studies allowed identification of useful features in systematic and phylogenetic contexts. In armadillos, osteoderms are constituted by compact bone tissue (primary and secondary osteons, and concentric layers or lamellae) that delimits cavities, which could contain different soft tissues (adipose tissue, hair follicles, bone marrow, and sweat and sebaceous glands). Traditional paleohistological techniques have allowed the recognition of homologous cavities to those found in osteoderms of current species and from comparison deduce which kind of tissue could had occupied them. We have recently utilized 3D reconstructions in osteoderms of extant species of armadillos to analyze the micromorphology, disposition, and the relationship of different cavities and understand them in depth. Here, we present the results of the application of paleohistology and microtomography in osteoderms of
\end{abstract}

M. R. Ciancio

mciancio@fcnym.unlp.edu.ar

1 División Paleontología Vertebrados, Museo de La Plata, CONICET, Facultad de Ciencias Naturales y Museo, Universidad Nacional de La Plata, Paseo del Bosque s/n, B1900FWA, La Plata, Argentina

2 Departamento de Ambiente y Turismo, Universidad Nacional de Avellaneda, España 350 Avellaneda, Buenos Aires, Argentina

3 Laboratorio de Métodos Analíticos, YPF Tecnología (Y-TEC), Avenida del Petroleo s/n, Berisso, Buenos Aires, Argentina representatives of diferent taxa of extinct Dasypodidae (Astegotheriini, Stegotheriini, "Utaetini," Euphractini, Eutatini), which allowed us to compare homologous structures based on their three-dimensional reconstruction. The results, added to the previous external morphology studies, have allowed us to define morphological patterns (consistent within each linage). The variation of the volume and extension of cavities associated with different tissues could be strongly associated with changes in the climate and environmental conditions of the species distribution areas.

Keywords Dasypodidae $\cdot$ Paleohistology $\cdot$ Dermal ossifications $\cdot$ Early Cenozoic

\section{Introduction}

Xenarthrans constitute a distinctive mammal clade of the South American fauna; they have a long evolutionary history, from the early Eocene to the present. One of the most conspicuous characteristic of this group is the presence of osteoderms (Ciancio 2016 and references therein). These bone pieces are frequent in many tetrapod groups (Vickaryous and Sire 2009), but within Mammalia they are exclusive to Xenarthra. They can be found in some Pilosa and they clearly characterize the clade Cingulata, which are currently represented by the armadillos.

In Cingulata, the osteoderms are interlocking, forming dorsal protective coverings: a cephalic shield, which covers the head; a caudal sheath, encasing the tail, and a dorsal carapace, covering the rest of the body dorsally and on the sides. Each carapace is constituted by many individual osteoderms, which represent the most frequently preserved remains in the fossil record, being found in almost every South American mammal fauna known since 
the Eocene (Carlini et al. 2010; Ciancio et al. 2013; Soibelzon et al. 2013, 2015; Rodriguez-Bualó et al. 2014).

The external morphology of the osteoderms has a high diagnostic value; it has been used to describe many species (particularly those from the early-middle Cenozoic) (Scillato-Yané 1982; Vizcaíno 1994a; Carlini and Scillato-Yané 1996; Fernícola and Vizcaíno 2008; Carlini et al. 2010), and it has been very useful for identifying the presence of species in the paleontological and archaeological records (Soibelzon et al. 2006, 2010; Francia and Ciancio 2013; González-Ruiz et al. 2013; Dozo et al. 2014; Soibelzon and León 2017, among others). However, the major carapace features or the osteoderm morphology have not been employed in the majority of the phylogenetic analyses of cingulates, and because of that, integration between alpha taxonomy and cladistics has not been reached. Usually, teeth, skull, and appendicular characters have been used (Engelmann 1985; Gaudin and Wible 2006; Porpino et al. 2009; Billet et al. 2011), and only a few analyses have included dorsal carapace features (Hill 2005; Abrantes and Bergqvist 2006; Zurita et al. 2013; Castro et al. 2015).

In recent years, histology and paleohistology have been used as tools for the study of osteoderm microstructure and its relation to soft tissues (Hill 2006; Scheyer and SánchezVillagra 2007; Vickaryous and Sire 2009; Wolf et al. 2012; Vickaryous and Hall 2006; Krmpotic et al. 2009b, 2015). The importance of osteoderm internal morphological studies for the reconstruction of evolutionary patterns has been pointed out in many cases, given that the information obtained from inferring the presence of certain soft tissues in fossils is as important as the bony pieces themselves, because they can offer paleobiological and phylogenetic information (Witmer 1995; Hill 2005).

The osteoderms of tetrapods share certain features in common (e.g., origin within the dermis, structural composition based on bone tissue, development by metaplastic or intramembranous ossifications, see Vickaryous and Sire 2009; Krmpotic et al. 2015). In adult cingulates, osteoderms are primarily formed by an external zone and an internal zone of non-Haversian compact bone, and a middle zone with primary and secondary osteons, with concentric lamellae encircling large cavities (Hill 2006; Vickaryous and Hall 2006; Krmpotic et al. 2009b, 2015).

The osteoderm structure of Cingulata, unlike other vertebrates, shows a complex association of many soft tissues (hair, glands, adipose tissue, bone marrow, blood vessels, and nerves) that are interrelated within a defined bone structure (Hill 2006; Vickaryous and Hall 2006; Krmpotic et al. 2009a, b, 2015; Wolf et al. 2012). Therefore, beside their own bone tissue morphology of which they are made, armadillo osteoderms have an internal architecture organized to contain those soft tissues.
From the information obtained in the analysis of modern armadillos, the presence of certain soft tissues can be inferred, defined by the internal bone structure and the threedimensional arrangement of bone in the fossil osteoderms (Krmpotic et al. 2015 and references within). In this study, we describe internal morphology of fossil osteoderms from the main lineages present during the early Cenozoic in Patagonia (Argentina); we define some morphological patterns and we analyze those patterns; from an evolutionary point of view and in relation to changes in paleoenvironmental conditions.

\section{Materials and Methods}

For this study, the osteoderms of the main groups of armadillos for the early Cenozoic of Patagonia (Argentina) were studied (see Table 1): Dasypodinae: Astegotheriini, Stegosimpsonia sp. and Astegotherium dichotomus (early middle Eocene); Stegotheriini, Stegotherium variegatum (early Miocene). Euphractinae: Utaetus buccatus ("Utaetini", late middle Eocene); Euphractini, Parutaetus chicoensis (late Eocene); Eutatini, Sadypus sp. (early Oligocene) and Meteutatus lagenaformis (late Oligocene). The study of the internal morphology was made using two techniques: paleohistological and microtomographic. For a comparative framework, we use published data from osteoderms of extant armadillos (Dasypus for Dasypodinae and Chaetophractus for Euphractinae) or latest relatives in fossil lineages (Eutatus for Eutatini).

Paleohistological Techniques Osteoderms were mechanically prepared (for coarse fraction sediments) and by means of 100 volume hydrogen peroxide (1:10) (for fine fraction), to remove sediment from pores, foramina, and cavities. Next, they were embedded in colored polyester resin and placed in a vacuum chamber to remove air bubbles. Once the resin solidified, preparations were sliced using a metallographic cutter and then polished with a metallographic grinding disc to obtain thin sections. Digital photographs were obtained sequentially.

Microtomography The digital radiographic images were acquired on a SkyScan $1173 \mu$-CT with a interslice distance of $40 \mu \mathrm{m}$. The 3D reconstructions were performed using Nrecon software v. 1.6.9.8. The radiographic images as well as the 3D reconstructions were realized in Y-TEC (YPF Tecnología) facilities.

\section{Internal Cavities of Osteoderms}

Being based on Krmpotic et al. (2009b, 2015), different types of cavities were defined, according to their morphology and to the soft tissues they encase. Comparing the architecture of the fossil osteoderms internal cavities with those found in current 
Table 1 List of specimens included in this paper

\begin{tabular}{|c|c|c|c|}
\hline Colection number & Taxon & Age & Locality \\
\hline Field \# 07-67 & Stegosimpsonia sp. & $\begin{array}{l}\text { early middle Eocene, Vacan Subage } \\
\text { of Casamayoran SALMA }\end{array}$ & $\begin{array}{l}\text { Cañadon Vaca, Provincia del Chubut, } \\
\text { Patagonia, Argentina. }\end{array}$ \\
\hline Field \# 07-68 & Astegotherium dichotomus & $\begin{array}{l}\text { early middle Eocene, Vacan Subage } \\
\text { of Casamayoran SALMA }\end{array}$ & $\begin{array}{l}\text { Cañadon Vaca, Provincia del Chubut, } \\
\text { Patagonia, Argentina. }\end{array}$ \\
\hline Field \# 97-Toco 1 & Stegotherium variegatum & early Miocene, Colhuehuapian SALMA & $\begin{array}{l}\text { Gran Barranca, Provincia del Chubut, } \\
\text { Patagonia, Argentina. }\end{array}$ \\
\hline MPEF PV 5426 & Utaetus buccatus & $\begin{array}{l}\text { late middle Eocene, Barrancan Subage } \\
\text { of Casamayoran SALMA }\end{array}$ & $\begin{array}{l}\text { Gran Barranca, Provincia del Chubut, } \\
\text { Patagonia, Argentina. }\end{array}$ \\
\hline MPEF PV 7378D & Parutaetus chicoensis & late Eocene, "El Nuevo" fauna (GBV-60) & $\begin{array}{l}\text { Gran Barranca, Provincia del Chubut, } \\
\text { Patagonia, Argentina. }\end{array}$ \\
\hline MPEF PV 5705 & Meteutatus lagenaformis & late Oligocene, Deseadan SALMA & $\begin{array}{l}\text { Cabeza Blanca, Provincia del Chubut, } \\
\text { Patagonia, Argentina. }\end{array}$ \\
\hline Field \# 95-065 & Sadypus sp. & early Oligocene, predeseadan fauna & $\begin{array}{l}\text { La Curandera, Provincia del Chubut, } \\
\text { Patagonia, Argentina. }\end{array}$ \\
\hline MLP 61-VIII-3-289-307 & Sadypus sp. & early Oligocene, predeseadan fauna & $\begin{array}{l}\text { La Curandera, Provincia del Chubut, } \\
\text { Patagonia, Argentina. }\end{array}$ \\
\hline
\end{tabular}

forms, it has been inferred which kind (and in what proportion) of soft tissues it would have been present in the extinct taxa. In sagittal section, three zones are recognized in the thickness of the osteoderms (an external and an internal zone, and a middle zone between them) that contain most of the large cavities (Krmpotic et al. 2009a, b, 2015). As a result of reviewing the studies made on current armadillos representatives, three types of cavities were defined (Fig. 1):

1. Marginal piliferous follicle cavities $(m f c)$ : They typically are elongated cavities with an oblique arrangement (anteroventral to posterodorsal), which generally open on the osteoderms margins, mainly on the posterior margin. These cavities can have different morphologies and sizes. In extant species, these cavities contain a hair follicle that can be associated to an undeveloped sebaceous gland (Euphractinae) or to a sweat gland (Dasypodinae) (see Krmpotic et al. 2015).

2. Glandular cavities $(g c)$ : Saccular or spherical cavities generally placed at the middle zone of the osteoderms. They open vertically to the external surface (surface piliferous follicles in Krmpotic et al. 2015; external surface foramina, "esf," in Krmpotic et al. 2009b). These cavities can be found at different depths of the osteoderm thickness and they can open into the osteoderm surface through thin channels or through a wide connection without decreasing the diameter. In extant armadillos these cavities contain typically sweat and sebaceous glands associated with a hair follicle, although

Fig. 1 Buckler osteoderms from the pelvic buckler. $a$.

Chaetophractus villosus, $b$.

Dasypus hybridus. 1. osteoderms

in external view, 2. 3D

reconstructions of the internal morphology of the non-skeletal area of the osteoderm. External contour of the osteoderms in translucent (blue); bmc, bone marrow cavities (yellow); esf, external surface foramina; gc, glandular cavity (green); mfc, piliferous follicule cavity (red); pf, piliferous foramina. Scale bar $5 \mathrm{~mm}$

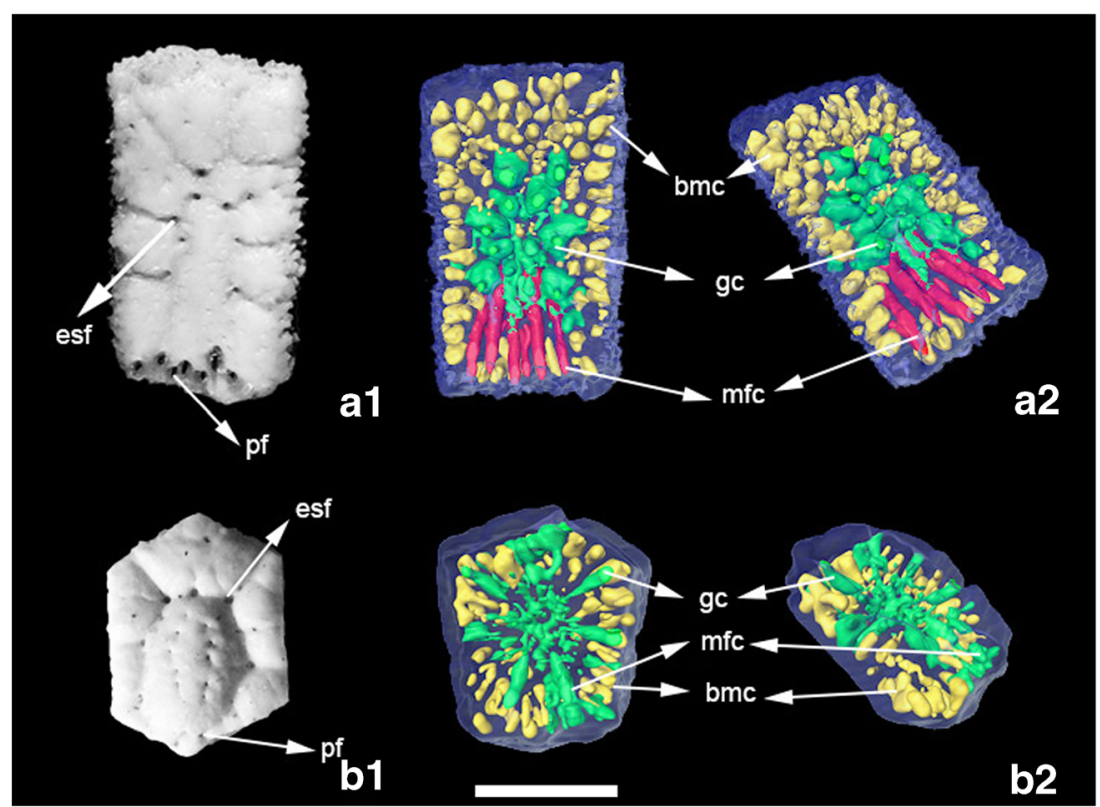


occasionally one of these structures could be missing or undeveloped (e.g., piliferous follicles in adult euphractins, Krmpotic et al. 2009b, 2015).

3. Bone marrow cavities $(b m c)$ : These cavities can be found in the middle zone of the osteoderm and they can be differentiated from other cavities because they have no direct connection to the exterior. Among extant armadillos, these cavities typically contain yellow bone marrow (adipose tissue), although the red bone marrow can also be found. Euphractins (e.g., Chaetophractus villosus, Fig. 1a) present more numerous and larger cavities filled with adipose tissue (yellow bone marrow) in the middle zone of the buckler and movable osteoderms (Krmpotic et al. 2009a, b, 2015). In dasypodins the $b m c$ show different range of development. They are always present in the cranial portion (anterior articular surface in Hill 2006 or overlapped portion) of the movable osteoderms, and they could be filled with red or yellow bone marrow. But, their presence in the exposed portion of the movable osteoderms and buckler osteoderms, has been recorded only in Dasypus hybridus (Fig. 1b) (Hill 2006; Krmpotic et al. 2009a, b, 2015).

There are also small elongated cavities that open on the inner surface of the osteoderm. These openings correspond to the entrance of neurovascular bundles, which branch and run into the osteoderms. These channels have a very small diameter, and some of them open on the outer surface of the osteoderms..

\section{Results}

DASYPODIDAE Gray, 1821

DASYPODINAE Gray, 1821

ASTEGOTHERIINI Ameghino, 1906

\section{Stegosimpsonia $\mathrm{sp}$.}

(Table 1, Fig. 2a)

The osteoderms show a compact arrangement. The only cavities present in the middle zone of the osteoderms are those corresponding to $g c$ and $m f_{c}$ (Fig. 2: a2). In the buckler osteoderms, the $g c$ are spherical and proportionally well developed, and the channels that open to the exterior (external surface foramina) are short and wide; the $m f c$ have a similar morphology but their opening is oblique and they are not very deep, not passing half of the thick of the osteoderm. The movable osteoderms have $g c$ with the same morphology as the buckler osteodems, but the $m f c$ are small, thin, and long. The $b m c$ can be found only in the cranial portion of the movable osteoderm, but they are poorly development.
Astegotherium dichotomus Ameghino, 1902

(Table 1, Fig. 2b)

As can be seen in Stegosimpsonia, the osteoderms are compact structure without $b m c$. Usually, the osteoderms also lack the $g c$ (Fig. 2: b1), but can be present in some buckler osteoderms and have the same morphology as in Stegosimpsonia (Fig. 2: b2). Few marginal piliferous foramina can be found in some osteoderms. Internally, these foramina are continuous with the $m f c$, which are long and small.

\section{STEGOTHERIINI Ameghino, 1889}

Stegotherium variegatum Ameghino, 1902

(Table 1, Fig. 3)

The most characteristic feature of Stegotheriini is the presence of numerous piliferous foramina surrounding the lateral and posterior margins of the osteoderms, and even anterior to the main figure. Those foramina are the opening of long $m f c$, which occupy much of the middle zone of the osteoderm. These have the typical morphology described for armadillos (long, tubular, and obliquely arranged, see above). However, unlike Euphractinae, the deepest part of the $m f_{c}$ is distinctly globular. Buckler osteoderms have a pair of $g c$ with morphology similar to those in Astegotheriini, but with a bigger connection to the exposed surface, represented by a pair of big external surface foramina. Despite the great amount of hair follicle associated cavities, the general arrangement of the bone structure of the osteoderm is compact. No bmc can be identified in buckler osteoderms. In movable osteoderms bmc can only be found in the cranial portion, with a greater development in comparison to Stegosimpsonia. The gc in the movable osteoderms are associated with the $m f c$ and form a compound structure where the cavities join together and open into the external surface of the osteoderm.

\section{EUPHRACTINAE Winge, 1923}

\section{Utaetus buccatus Ameghino, 1902}

(Table 1, Fig. 4a)

The osteoderms, in sagittal section, show external and internal compact zones and a well-defined middle zone with numerous cavities $(b m c, g c$, and $m f c$ ). The $g c$ are typically four (anterior and posterior pairs). The piliferous foramina are restricted to the posterior end of the osteoderms. Internally, $m f_{c}$ have the typical morphology described above, but not surpassing the middle zone in thickness. In the dorsal shield of Utaetus, there are two morphologies of osteoderms according to their relative position in the carapace. However, one morphological pattern can be defined, but with changes in the relative 
Fig. 2 Astegotheriins. $a$. Movable and buckler osteoderms of Stegosimpsonia. 1. osteoderms in external view; 2 .

paleohistological sections (longitudinal) of buckler osteoderms, showing the general internal arrangement; 3. 3D reconstructions of the internal morphology of the non-skeletal area of the buckler osteoderm; 4. $3 \mathrm{D}$ reconstructions of the internal morphology of the non-skeletal area of the of movable osteoderm. $b 1, b 2$. Buckler osteoderms of Astegotherium dichotomus, external view and paleohistological sections (longitudinal) showing the internal morphology. External contour of the osteoderms in translucent (blue); bmc, bone marrow cavities (yellow); esf, external surface foramina; gc, glandular cavity (green); mfc, piliferous follicule cavity (red); pf, piliferous foramina. Scale bar $5 \mathrm{~mm}$

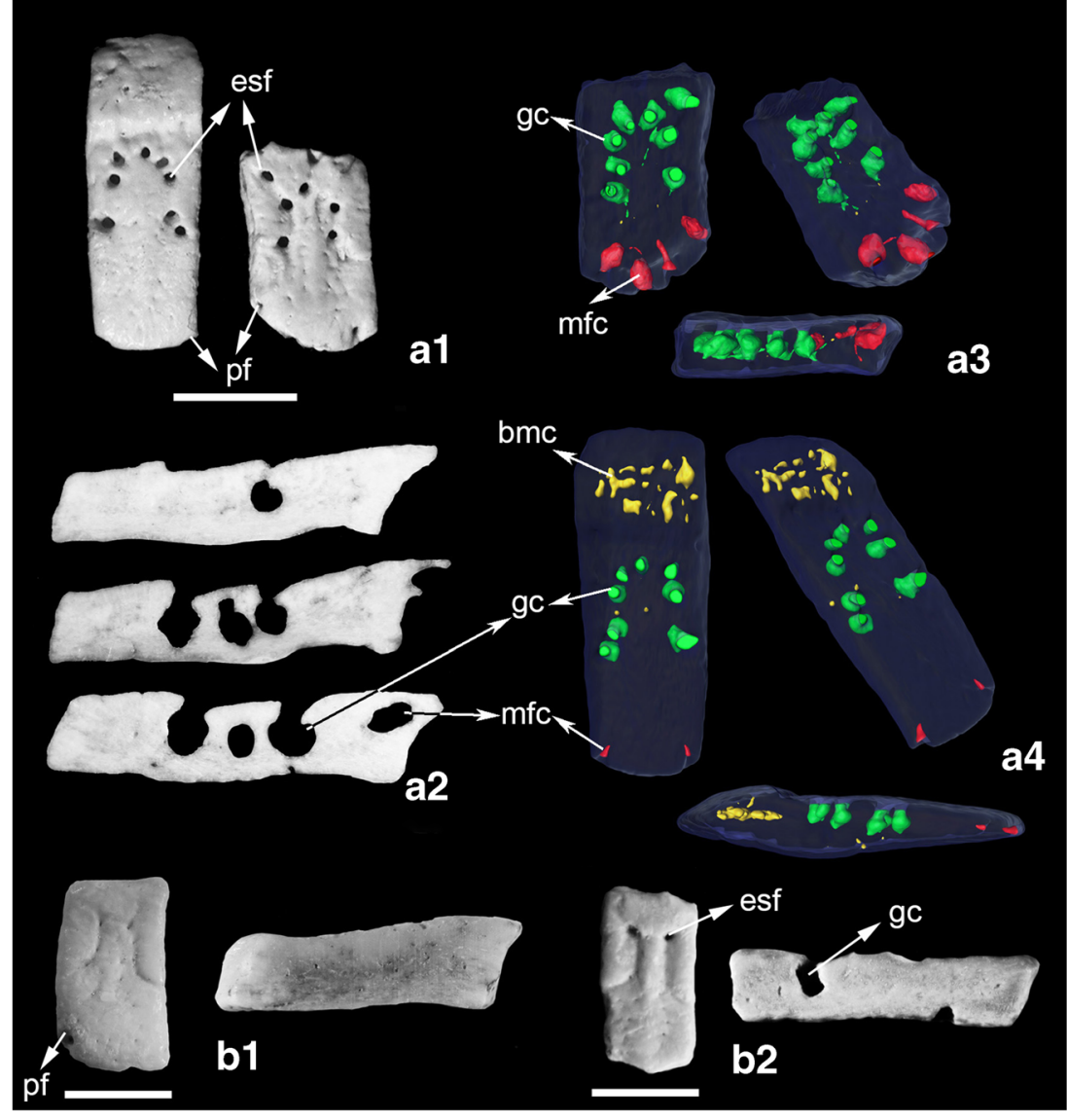

development of different structures. In the medial region of the carapace, osteoderms have large foramina on the external surface that are connected to large spherical $g c$ (Fig. 4: a5). In the osteoderms of lateral areas of the carapace, the $g c$ are smaller and the connection to the outside is through a narrow passage that opens in small external foramina (Fig. 4: a4). Movable osteoderms (Fig. 4: a2, a6, a7) have the same structural pattern in their internal morphology as buckler ones. The $m f c$ are placed towards the posterior vertices of the osteoderms.

\section{EUPHRACTINI Winge, 1923}

Parutaetus chicoensis Ameghino, 1902

(Table 1, Fig. 4b)

Internal structure of buckler osteoderms shows a middle zone, with the presence of numerous $b m c$ of various sizes, $g c$, and $m f c$. The $g c$ are spherical and connecting to the foramina on the external surface through relatively narrow conduits. On the posterior margin, tubular and thin $m f c$ can be observed; they do not exceed the middle zone, and open into small marginal foramina on the posterior margin. Internal and external zones are compact and thicker than the middle zone.

\section{EUTATINI Bordas, 1933}

Meteutatus lagenaformis (Ameghino, 1897) and Sadypus sp. (Table 1, Fig. 5a Meteutatus lageniformis and 5b Sadypus sp.)

Osteoderms show an internal and external zone relatively thin of compact bone. The middle zone is wide and forms most of the thickness of the osteoderm; it is occupied by numerous $b m c$ and a great development of $m f c$. Paleogene eutatins studied here lack exposed surface foramina, and this is consistent with the absence of $g c$ inside the osteoderm. One of the most evident features that characterize Eutatini is the great development of the piliferous system, which is restricted to the posterior border of the osteoderm and occupies the last part of the external surface (Carlini et al. 2009, 2010). In Meteutatus (Fig. 5a), individual $m f c$ converge into larger cavities that end in large foramina on the posterior margin. In Sadypus (Fig. 5b), the morphology of the piliferous complex is a bit different. Each individual $m f_{c}$ opens independently into a larger posterior opening that occupies almost all the posterior border. Movable osteoderms of both taxa show the same morphology as buckler osteoderms, in the structures that make up the osteoderms. 
Fig. 3 Stegotheriins. $a$. Buckler (left), semimovable (middle) and movable (right) osteoderms of Stegotherium variegatum. $b$. paleohistological sections (longitudinal) of buckler osteoderms of Stegotherium variegatum. c-e. $3 \mathrm{D}$ reconstructions of the internal morphology of the non-skeletal area of: $c$. buckler osteoderm, $d$. semimovable osteoderm, e. movable osteoderms. External contour of the osteoderms in translucent (blue); bmc, bone marrow cavities (yellow); esf, external surface foramina; gc, glandular cavity (green); mfc, piliferous follicule cavity (red); pf, piliferous foramina. Scale bar $5 \mathrm{~mm}$

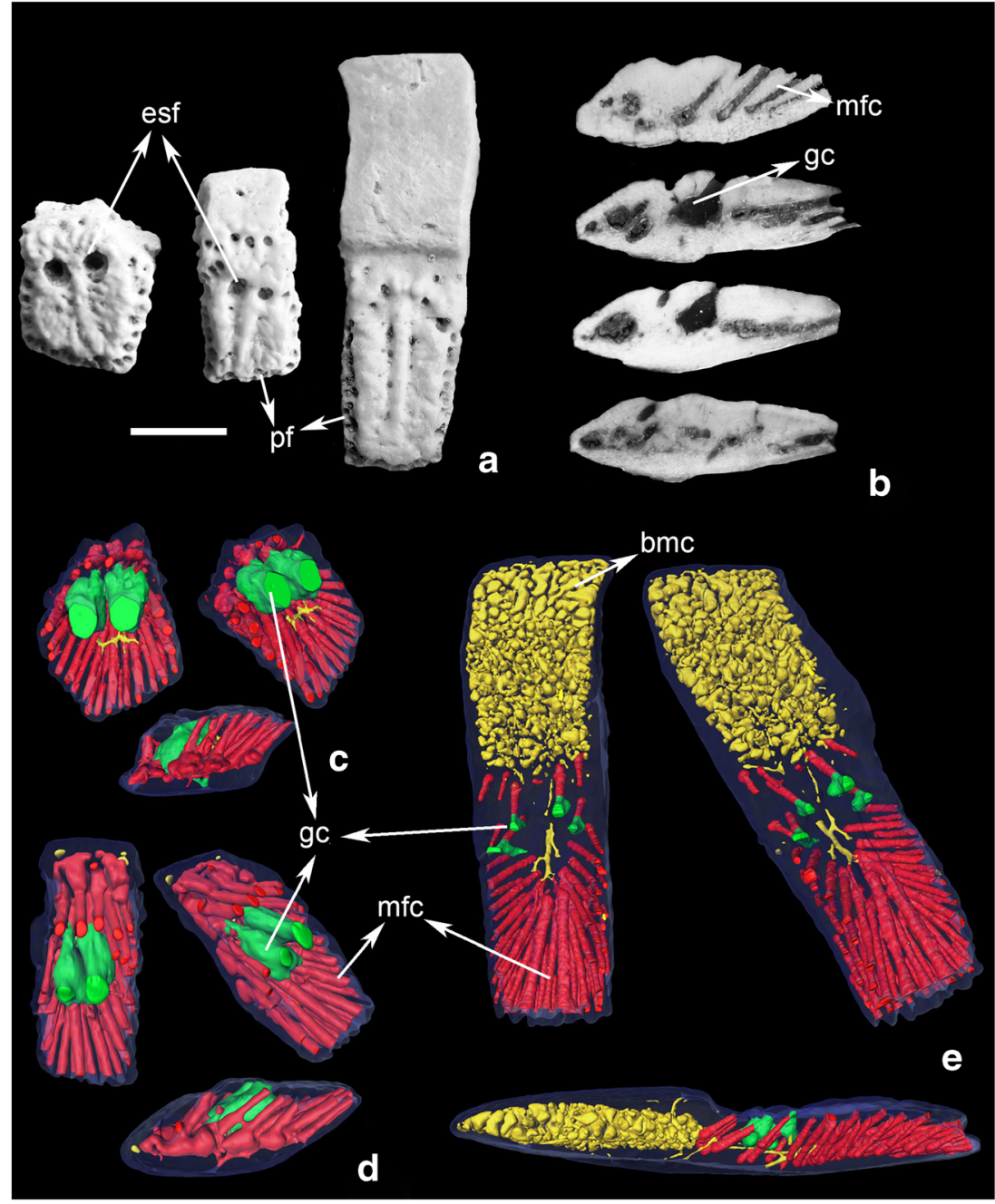

\section{Discussion}

Among xenarthrans, the presence of osteoderms is typical of cingulates, but not exclusive. Some fossil pilosan (e.g., Mylodon, Glossotherium) have osteoderms, but they do not form a carapace. These dermal ossifications are composed of compact bone, without cavities, given that they are not integrated with other integumentary soft tissues (Holmes and Simpson 1931; Hill 2006; Ciancio 2010).

In cingulates, the osteoderm micromorphology also shows a distinctive pattern in the different lineages. Glyptodonts have osteoderms with a typical diploë-like structure that consists of a region of trabecular bone interposed between superficial and deep layers of compact bone (Hill 2006; Carlini et al. 2008; Ciancio 2010; Wolf et al. 2012; Da Costa et al. 2014). On the other hand, dasypodids show an external zone of non-Haversian compact bone (consisting of bone tissue without cavities with no concentric lamellae forming Haversian systems), a middle zone with primary and secondary osteons, with concentric lamellae encircling large cavities (with variable development, and containing different soft tissues), and an internal layer of non-Haversian compact bone (composed of collagen bundles that run parallel to the surface) (Krmpotic et al. 2015).

The general conformation of osteoderms is similar in all armadillos and it is possible to define a general pattern that characterizes them, although there are several differences in their micromorphology among the different lineages. Based on extant species, Krmpotic et al. (2015) proposed several differences between the most diverse subfamilies (Euphractinae and Dasypodinae): a) euphractins present more numerous and larger cavities filled with adipose tissue (yellow bone marrow) in the middle zone of the osteoderms, as well as more marginal follicles than the Dasypodinae; b) glandular cavities occupied by the

Fig. 4 Euphractins. a. Utaetus buccatus, external view of buckler (a1) and movable (a2) osteoderms. a3, paleohistological sections (longitudinal) of buckler osteoderm. $a 4-a 7,3 \mathrm{D}$ reconstructions of the internal morphology of the non-skeletal area of buckler and movable osteoderms $b$. Parutaetus chicoensis. $b 1$, external view of a buckler osteoderm. $b 2$, paleohistological cross section (left) and longitudinal section (right). External contour of the osteoderms in translucent (blue); bmc, bone marrow cavities (yellow); esf, external surface foramina; gc, glandular cavity (green); mfc, piliferous follicule cavity (red); pf, piliferous foramina. Scale bar $5 \mathrm{~mm}$ 


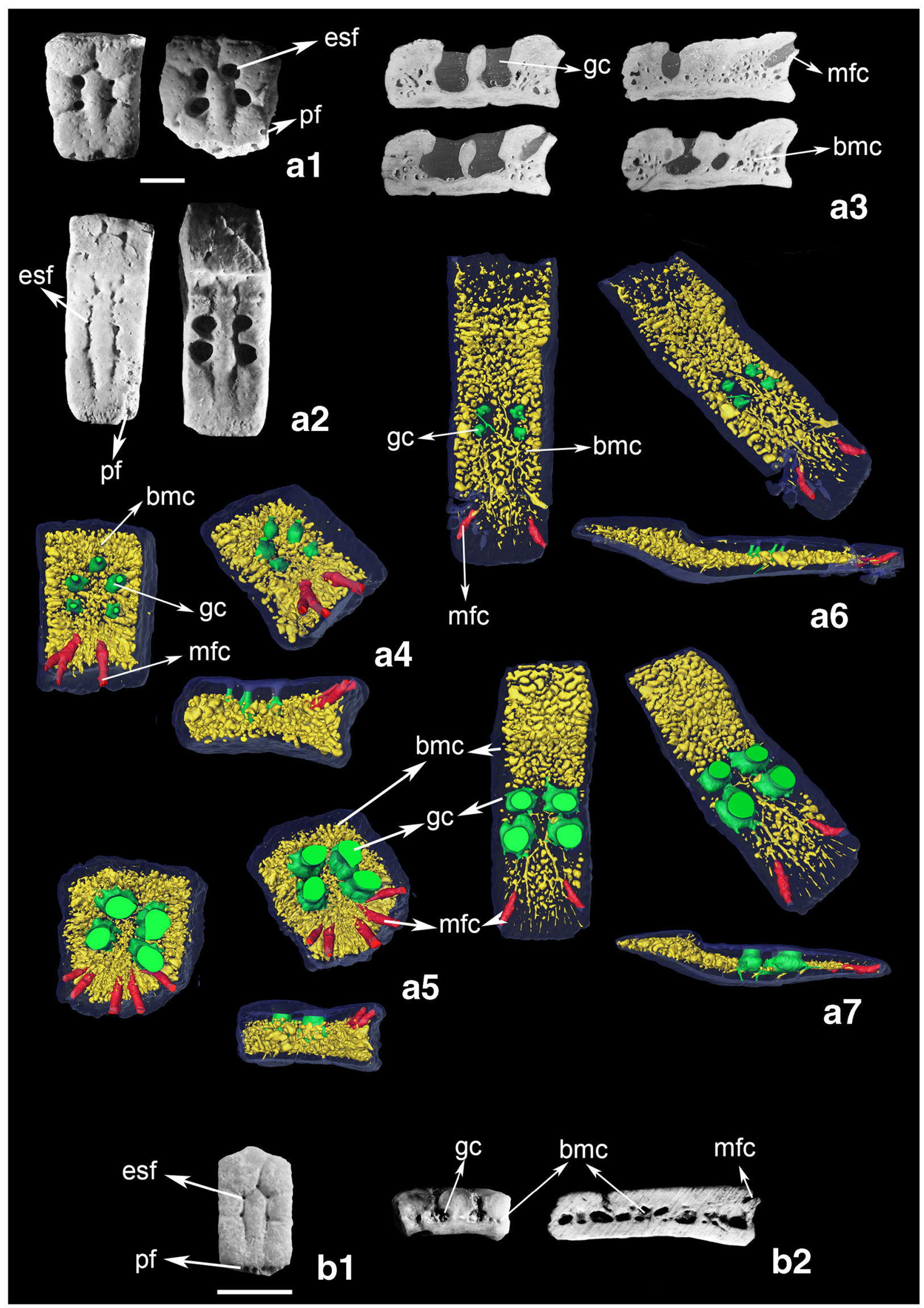




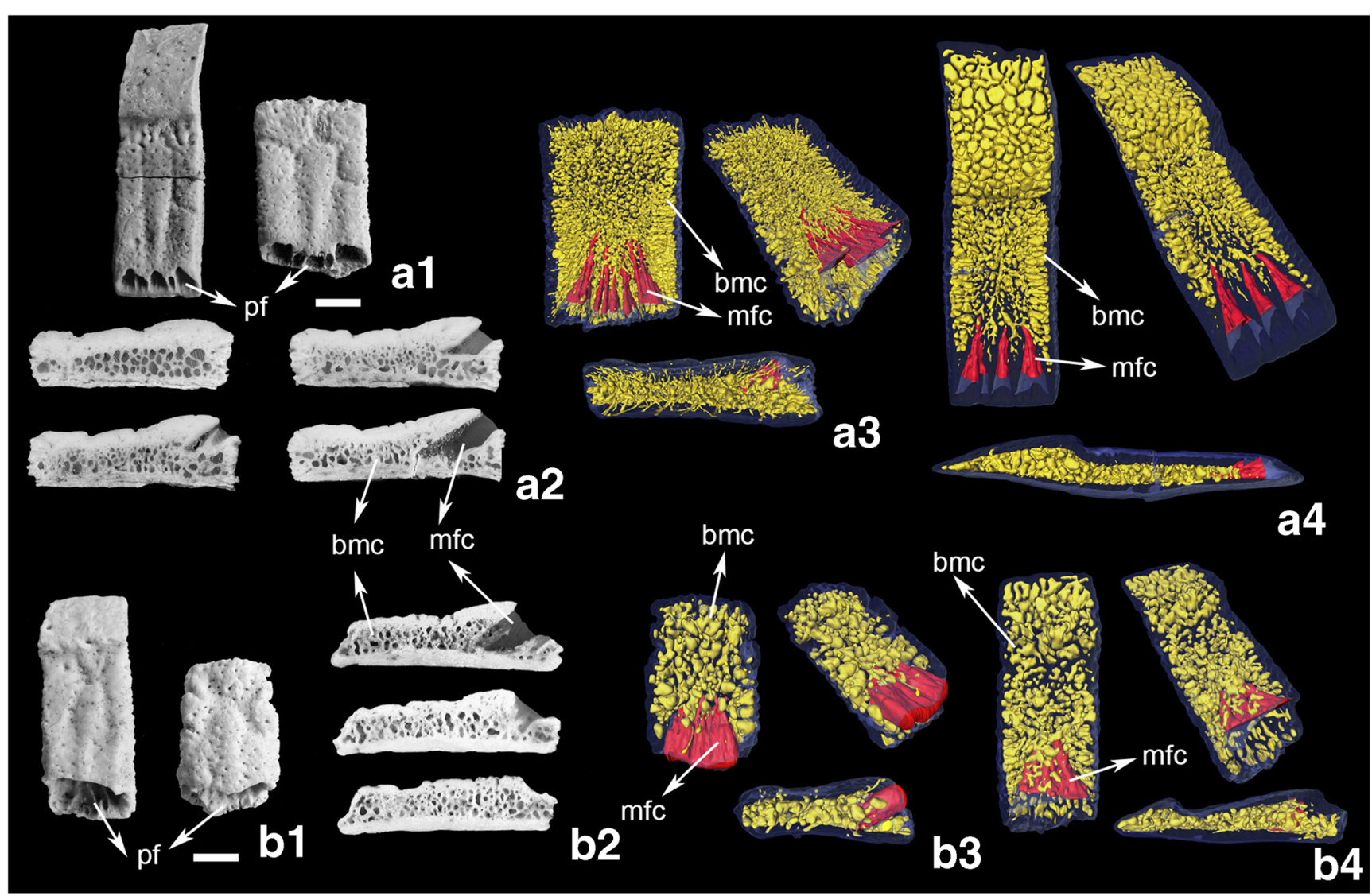

Fig. 5 Eutatins. a. Meteutatus lagenaformis. al, external view of movable (left) and buckler (right) osteoderms. a2, paleohistological sections (longitudinal) of buckler osteoderm. $a 3-a 4,3 \mathrm{D}$ reconstructions of the internal morphology of the non-skeletal area of buckler and movable osteoderms. b. Sadypus sp. b1, external view of movable (left) and buckler (right) osteoderms. $b 2$, paleohistological sections (longitudinal) of buckler osteoderm. $b 3-b 4,3 \mathrm{D}$ reconstructions of the internal morphology of the non-skeletal area of buckler and movable osteoderms. External contour of the osteoderms in translucent (blue); bmc, bone marrow cavities (yellow); $\mathrm{mfc}$, piliferous follicule cavity (red); pf, piliferous foramina. Scale bar $5 \mathrm{~mm}$ surface follicles and sebaceous glands are much more developed in the Euphractinae, although these hairs are not always present in postnatal stages; c) cavities occupied by marginal follicles of Euphractinae are more developed and have a tubular morphology; the piliferous follicles in Dasypodinae are generally associated with sweat glands (and occasionally with sebaceous glands), whereas in Euphractinae they are associated only with sebaceous glands.

The study of inner morphology (by paleohistology and 3D reconstruction) of osteoderms on extinct armadillos, and the histological information from current representatives, allowed us to deduce what soft tissues might have occupied the different spaces into the osteoderms. According to the characteristics of these structures and the way in which these tissues are represented, it has been possible to identify certain morphological-structural patterns that characterize different lineages of Cenozoic dasypodids, their changes, and the possible influence of climate factors on this changes.

The climatic-environmental scenario has been in continuous change throughout the Cenozoic and these oscillations have influenced the temporal and spatial distribution of the species (Fig.
6). In Patagonia (Argentina), it is possible to observe a series of environmental changes (influenced by different global and regional factors) in a continuous time sequence (Legarreta and Uliana 1994; Zachos et al. 2001; Ortiz-Jaureguizar and Cladera 2006). In particular, cladogenesis of armadillos and their differential distributions have been closely influenced by climaticenvironmental conditions and their variations over time (Carlini et al. 2009, 2010; Ciancio et al. 2013; Krmpotic et al. 2015).

The oldest known armadillos come from sediments corresponding to the early Eocene (Ciancio et al. 2013) (Fig. 6). During this time, paleoclimatic conditions in Patagonia indicate a warm and humid period (with greater values than those of the present day). This is known as the Early Eocene Climatic Optimum (EECO) (Pascual et al. 1996; Zachos et al. 2001; Goin et al. 2016). This first known armadillos were represented by Astegotheriini (Dasypodinae) (Fig. 2), which are characterized by having solid osteoderms with $b m c$ only restricted to a cranial portion of movable osteoderms, and a poor development of their pilosity. The cavities developed in buckler osteoderms have a similar morphology, making it difficult to differentiate between $g c$ from $m f c$, the last ones showing only an oblique 


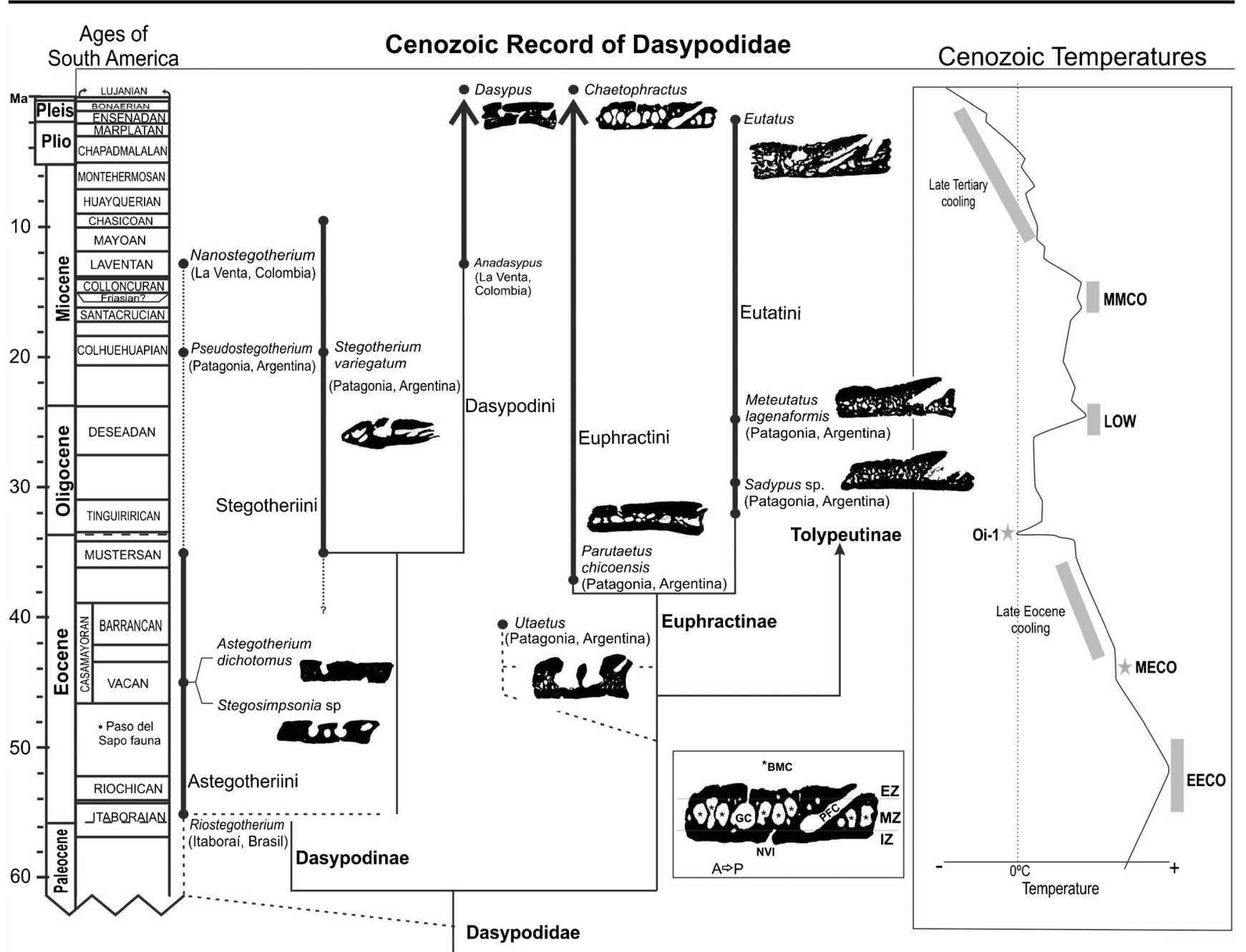

Fig. 6 Approximate temporal placement of Cenozoic dasypodidcontaining faunas discussed in the text, in relation to Cenozoic the main climatic events. The taxa of Dasypodidae studied in this work are represented in a simplified phylogenetic relationship of fossil and extant xenarthrans based on morphological and molecular results (Asher et al. 2009; Billet et al. 2011; Delsuc et al. 2012; Meredith et al. 2013). Phylogenetical position of taxa not included in known phylogenetic analyses was inferred based on the literature and taxonomical position. Histological and paleohistological sections of dasypodid osteoderms included in this study are representated as binary images. Thick lines indicate the biocron, circles indicate first and last record, thin dash lines

disposition instead of a vertical one. This indicates that both cavities could be containing the same structures, probably a complex composed of a sweat gland associated with a hair and also a sebaceous gland. A similar condition could be observed in extant dasypodines, Dasypus (Dasypodini, Dasypodinae) (Fig. 1b), which shows a $g c$ and $m f c$ with similar structure, and both structures can have two gland types (sweat and sebaceous) associated whith a hair follicle (Hill 2006; Krmpotic et al. 2015).

Main changes in the internal morphology of armadillo osteoderms can be seen during the mid-late Eocene; in this lapse the diversity of euphractins increases and the diversity of astegotheriins decrease. The changes are the greater indicate absence of record and dashed lines possible group relationships. The temperature scale (inferred from oceanic $\delta^{18} \mathrm{O}$ ) and events is based on Zachos et al. (2001), Ciancio et al. (2013), and Goin et al. (2016). $\mathrm{BMC}$, bone marrow cavities; EECO, climatic optimum of the early Eocene; EZ, external zone; GC, glandular cavity; IZ, internal zone; MECO, climatic optimum of the middle Eocene; MZ, middle zone; Oi1 , Oligocene event, associated with extreme cooling, recorded in the oxygen isotope values of marine carbonates; PFC, piliferous follicule cavity; LOW, late Oligocene warming; MMCO, climatic optimum of the middle Miocene; NVI, neuro-vascular ingression

development of $b m c$, occupying most of the middle zone in all osteoderms (such as observed in "Utaetini", Euphractini and Eutatini) and a greater $m f c$ development, that clearly indicates further development of pilosity. The increases of $b m c$ could be interpreted as a development of a defined layer of adipose tissue in the osteoderm (see Krmpotic et al. 2015).

In basal Euphractini/ae, "Utaetini," Utaetus (Fig. 4a; see Carlini et al. 2010), we observe a middle zone in the osteoderm, characterized mainly by the presence of $b m c$. The $g c$ are well developed and their morphology varies with the osteoderm morphological variation inside the carapace. The morphological differentiation of these structures in different carapace areas would 
depict an area (in the medial zone of the carapace) with larger glandular development. The $m f c$ are tubular and elongated and they are not deeper than the middle zone.

Fossil Euphractini are represented here by Parutaetus, a small Euphractini from the Eocene (Fig. $4 \mathrm{~b}$ ). The osteoderms show a middle zone represented by numerous $b m c$ and $g c$ with narrow connections to the surface. The $m f c$ are elongated and do not surpass the middle zone in depth. The general structure of the osteoderms shows a similar pattern as that described for current species (e.g., Zaedyus, Chaetophractus) (see Krmpotic et al. 2009b, 2015). In extant euphractins, the $g c$ contain sweat and sebaceous glands, and they are generally associated with a hair follicle (Krmpotic et al. 2009b, 2015).

As those morphological changes occurred, a gradual lowering of temperatures is recorded (in Patagonia, Argentina) after EECO, which has its maximum expression during the Eocene-Oligocene transition (TEO), ("Oi- glaciation" see Zachos et al. 2001). Particularly when temperatures were at their lowest values, in higher latitudes, a great diversity of eutatines is recorded, and astegotheriins disappear from the fossil record (Fig. 6) (Ciancio and Carlini 2007; Krmpotic et al. 2009a, b; Carlini et al. 2010).

Eutatini (Euphractinae) (Fig. 5) have osteoderms with a great development of the middle zone (representing 50\% or more of the thickness), and larger $m f c$, which gather several hair follicles that open on the posterodorsal area of the osteoderm. Unlike the other Euphractinae taxa, $m f c$ reach the internal area and extend even more into the front end. Even, in Quaternary eutatins (Eutatus spp.), $m f_{c}$ reach and/or overpass half the osteoderm (Krmpotic et al. 2009a). The $m f c$ morphology indicates a great development of the Eutatini pilosity, a feature considered a characteristic of this group (Krmpotic et al. 2009a, b). The eutatins studied in this paper lack $g c$, but the presence of these structures is frequent in many taxa. Generally, the $g c$ of the osteoderms of Eutatini, have a spherical form and have thin conduits that connect to the exterior (Fig. 6) (Krmpotic et al. 2009a, b; Scillato-Yané et al. 2010).

Towards the last part of the early Oligocene, there is a small progressive increase in temperatures, which have their peak during the latest Oligocene ("Late Oligocene Warming," see Zachos et al. 2001). In this lapse, small size and with scarce pilosity Euphractini have been registered (e.g., Prozaedyus), along with a decrease of eutatin diversity; also Stegotherium (Stegotheriini) is recorded for first time.

Stegotheriini (Dasypodinae) constitute a quite peculiar group of armadillos and one of the most noticeable features is the presence of a great number of foramina on the margins and the surface of osteoderms (Fig. 3) (Carlini et al. 2010). These foramina have been described as hair follicles (Fernícola and Vizcaíno 2008), which may indicate hair abundance. Based on this study, this interpretation can be confirmed because these foramina are continuous with $m f c$. In buckler osteoderms, $g c$ are globular and have a wide connection to the surface, but in movable osteoderms each gland cavity is associated with a $m f c$, and both structures end in the exterior through the same conduit. As in other Dasypodinae (Astegotheriini, and most of Dasypodini), $b m c$ are restricted to the cranial portion (anterior overlapping portion) of the movable osteoderms. The first records of stegotheriins are middle-late Eocene, represented by small specimens (Carlini et al. 2010). However, the taxa included in this study, Stegotherium, is a relatively large armadillo frequently recorded from the earliest Miocene, when a warm climate with varied vegetation, like shrub steppes and savanna woodlands, had developed (Pascual and Odreman Rivas 1971; Pascual and Ortiz-Jaureguizar 1990; Vucetich and Verzi 1991 Vizcaíno 1994b).

The inner morphology of osteoderms among different lineages shows different characteristics that defined some patterns. The most variable structures are the cavities interpreted as bearing piliferous follicles $(m f c)$ and those occupied by bone marrow $(b m c)$. Among extant species of armadillos, the bone marrow cavities of the osteoderms contain red or yellow bone marrow (adipose tissue), but the last is prevalent (Krmpotic et al. 2009b, 2015).

Different studies have focused on measuring thermic conductivity of hair and fat in different mammal groups (e.g., Kvadsheim et al. 1994; Kvadsheim and Aarseth 2002; Liwanag et al. 2012). In these studies the great effectivity of adipose tissue as a thermal insulation has been demonstrated; among all biological molecule classes, lipids have the lowest thermal conductivity and the highest thermal insulation potential. In the case of the dermal adipose tissue, it has various functions: as an insulator, as an antibiotic tissue, and as a regenerative component for wound repair and hair growth (Alexander et al. 2015; and references therein). Hair structure and hair coat protect the skin against direct solar radiation, promote heat loss (by evaporation), or prevent the loss of body temperature (Davis and Birkebak 1974; Cena and Monteith 1975a, b).

McNab (1980) argued that the distribution of living armadillos would be closely related to the limitations established by their low body temperatures, low basal rates of metabolism, high minimal thermal conductance, and body size. The greater development of adipose tissue and hair coat could be associated with an adaptive mechanism for colder climates. Current representatives of euphractins are characterized by well-developed bone marrow cavities in the middle zone in buckler and movable osteoderms that are formed by yellow bone marrow (adipose tissue), abundance of piliferous follicles, and more development of glandular cavities. These characteristics could be associated with an adaptive mechanism for more arid and harsher environments with dryer and sandier soils and colder climates (Krmpotic et al. 2009a, b, 2015). On the other hand, the hair coat in living armadillos is more developed in species that inhabit colder climates, with marked seasonality, and low rainfall (Krmpotic et al. 2015; Feng et al. 2017). 
The fossil record shows an early diversification of Euphractinae towards the late Eocene, when global temperatures begin to fall progressively, and especially a diversification of Eutatini after the EOT, when a major cooling event is recorded (Zachos et al. 1994, 2001; Carlini et al. 2010; Ciancio et al. 2013; Goin et al. 2016). Therefore, the increase of the cavities that bear hair follicles and of the bone marrow cavities (associated with a greater development of the pilosity and adipose tissue) could be linked with the decrease of the global temperatures in that time period.

\section{Conclusions}

Histological techniques and computed microtomographies have proved to be useful tools for the study of dermal ossifications of armadillos. The characteristics of bone architecture (e.g., bone types, osteon morphology, bony layers arrangement, growth lines) could be complemented by the interpretation of what might have been the soft tissues associated with the spaces developed within of the osteoderm. These interpretations may provide new tools to understand different aspects of the biology of this particular group of mammals and their relationships.

Osteoderms represented only by compact bone, without cavities, not integrating other integumentary soft tissue, as can see in some fossil sloths, probably show the most primitive condition in xenarthrans. In Dasypodidae, the osteoderms are primarily composed of compact bone, in which a middle zone may be differentiated by the development of large cavities with concentric lamellae encircling primary and secondary osteons. These cavities could contain different soft dermal tissues (glands, bone marrow, hair follicles, vessels, and nerves).

The main differences between the known groups of Dasypodidae, Dasypodinae and Euphractinae as remarked by Krmpotic et al. $(2009 b, 2015)$ are also observed in fossil taxa. Dasypodinae are characterized by a compact osteoderm, with a variable degree of cavities for hair follicles and glands associated, but bone marrow cavities are absent or poorly development. Euphractins are characterized by the presence of well-developed bone marrow cavities occupying a large volume of the middle zone. The cavities bearing piliferous follicles have different degrees of development; these are restricted to a posterior or posterolateral borders, and more development of glandular cavities.

The presence of cavities with different morphologies in fossil osteoderms is associated with different soft tissues, and variation of the volume and extension of these cavities is different in each taxa. From the interpretation of the function of certain dermal tissues in extant species, some structural differences in the micromorphology of osteoderms in different taxa could be strongly associated with the climatic-environmental conditions of the distribution areas of the species.

\section{Data Availability}

The datasets generated and/or analyzed during the current study are available from the corresponding author on reasonable request.

Acknowledgments We acknowledge the curators that allowed the study of specimens under their care, Marcelo Reguero (División Paleontología de Vertebrados del Museo de La Plata, UNLP), Sr. Eduardo "Dudu" Ruigómez (Colección de Paleomastozoología del Museo Paleontológico "Edigio Feruglio"). We also thank E. Soibelzon, an anonymous reviewer, John Wible (Editor-in-chief), and Mariela Castro (Guest editor) for providing insightful comments and corrections that improved the manuscript. The digital radiographic images were acquired in YPF-Tecnología (Y-TEC). This work was supported by the Consejo Nacional de Investigaciones Científicas y Técnicas in Argentina (CONICET), Agencia Nacional de Promoción Científica y Tecnológica (BID - PICT 2013-2633, FONCyT-PICTO 105) y Universidad Nacional de La Plata (UNLP N-724).

\section{References}

Abrantes EAL, Bergqvist LP (2006) Proposta filogenética para os Dasypodidae (Mammalia: Cingulata). In: Gallo V, Brito PM, Silva HMA, Figueiredo FJ (Org) Paleontologia de Vertebrados: Grandes Temas e Contribuições Científicas. 1 ed. Interciência, Rio de Janeiro v 1, pp 261-274

Alexander CM, Kasza I, Yen CE, Reeder SB, Hernando D, Gallo RL, Jahoda CAB, Horsley V, MacDougald OA (2015) Dermal white adipose tissue: a new component of the thermogenic response. $\mathrm{J}$ Lip Res 56 (11): 2061-2069

Asher RJ, Bennett N, Lehmann T (2009) The new framework for understanding placental mammal evolution. BioEssays 31:853-864

Billet G, Hautier L, Muizon C de, Valentin X (2011) Oldest cingulate skulls provide congruence between morphological and molecular scenarios of armadillo evolution. Proc R Soc B 278: 2791-2797. doi: $10.1098 / \mathrm{rspb} .2010 .2443$

Carlini AA, Ciancio MR, Chimento NR (2008) Neoglyptatelus (Mammalia, Cingulata), caracteres y latitudes, en una discusión de afinidades. III Congreso Latinoamericano de Paleontología de Vertebrados Resúmenes: 49. Neuquén, Argentina

Carlini AA, Ciancio MR, Flynn JJ, Scillato-Yané GJ, Wyss AR (2009) The phylogenetic and biostratigraphic significance of new armadillos (Mammalia, Xenarthra, Dasypodidae, Euphractinae) from the Tinguirirican (early Oligocene) of Chile. J Syst Palaeontol 7(4):489-503

Carlini AA, Ciancio MR, Scillato-Yané GJ (2010) Middle Eocene-early Miocene Dasypodidae (Xenarthra) of southern South America, successive faunas in Gran Barranca; biostratigraphy and palaeoecology. In: Madden RH, Carlini AA, Vucetich MG, Kay RF (eds) The Paleontology of Gran Barranca: Evolution and Environmental Change through the Middle Cenozoic of Patagonia. Cambridge University Press, Cambridge, pp 106-129

Carlini AA, Scillato-Yané GJ (1996) Chorobates recens (Xenarthra, Dasypodidae) y un análisis de la filogenia de los Euphractini. Rev Mus La Plata (NS) 9 (59): 225-238

Castro MC, Ciancio MR, Pacheco V, Salas-Gismondi RM, Bostelmann JE, Carlini AA (2015) Reassessment of the hairy longnosed armadillo "Dasypus" pilosus (Xenarthra, Dasypodidae) and revalidation of the genus Cryptophractus Fitzinger, 1856. Zootaxa 3947(1):30-48

Cena K, Monteith JL (1975a) Transfer processes in animal coats. I. Radiative transfer. Proc R Soc Lond B 188: 377-393 
Cena K, Monteith JL (1975b) Transfer processes in animal coats. II. Conduction and convection. Proc R Soc Lond B 188: 395-411

Ciancio MR (2010) Los Dasypodoidea (Mammalia, Xenarthra) del Deseadense (Oligoceno) de América del Sur. Su importancia filogenética y bioestratigráfica. Unpublished Doctoral Thesis, Facultad de Ciencias Naturales y Museo, Universidad Nacional de La Plata, n 1098 . Pp. $290+$ XVI, 106 figures, 5 tables and 4 appendices

Ciancio MR (2016) Los armadillos (Dasypodidae, Xenarthra) del Cenozoico temprano-medio de Argentina: Aspectos evolutivos, bioestratigráficos y biogeográficos. Contrib Cient MACN "Bernardino Rivadavia" 6:231-247

Ciancio MR, Carlini AA (2007) Morfología del sistema pilífero en Eutatinos (Xenarthra, Dasypodidea) del Oligoceno de Patagonia (Argentina). III Congreso de Mastozoología en Bolivia. Santa Cruz de La Sierra, Bolivia. Resúmenes: 49-50

Ciancio MR, Carlini AA, Campbell, KE, Scillato-Yané, GJ (2013) New Palaeogene cingulates (Mammalia, Xenarthra) from Santa Rosa, Perú and their importance in the context of South American faunas. J Syst Palaeontol 11(6):727-741

Da Costa Pereira PVLG, Victer GD, Porpino KO, Bergqvist LP (2014) Osteoderm histology of late Pleistocene cingulates from the intertropical region of Brazil. Acta Palaeontol Pol 59 (3): 543-552

Davis LB, Birkebak CB (1974) On the transfer of energy in layers of fur. Biophysical Journal 14 (4):249-268

Delsuc F, Superina M, Tilak MK, Douzery EJ, Hassanin A (2012) Molecular phylogenetics unveils the ancient evolutionary origins of the enigmatic fairy armadillos. Mol Phylogenet Evol 62(2): 673-680

Dozo MT, Ciancio MR, Bouza P, Martínez G (2014) Nueva asociación de mamíferos del Paleógeno en el este de la Patagonia (provincia de Chubut, Argentina): implicancias biocronológicas y paleobiogeográficas. Andean Geol 41 (1): 224-247

Engelmann GF (1985) The phylogeny of the Xenarthra. In: Montgomery GG (ed) The Evolution and Ecology of Armadillos, Sloths and Vermilinguas. Smithsonian Institution Press, Washington, D.C., pp $51-64$

Feng X, Castro MC, McBee AK, Papeș M (2017) Hiding in a cool climatic niche in the tropics? An assessment of the ecological biogeography of hairy long-nosed armadillos (Dasypus pilosus). J Trop Conserv Sci 10:1-13

Fernícola JC, Vizcaíno SF (2008) Revisión del género Stegotherium Ameghino, 1887 (Mammalia, Xenarthra, Dasypodidae). Ameghiniana 45 (2): 321-332

Francia A, Ciancio MR (2013) First record of Chaetophractus villosus (Mammalia, Dasypodidae) in the late Pleistocene of Corrientes Province (Argentina). Rev Mus La Plata 13 (70): 1-9

Gaudin TJ, Wible JR (2006) The phylogeny of living and extinct armadillos (Mammalia, Xenarthra, Cingulata): a craniodental analysis. In: Carrano MT, Gaudin TJ, Blob RW, Wible JR (eds) Amniote Paleobiology: Perspectives on the Evolution of Mammals, Birds and Reptiles. University of Chicago Press, Chicago, pp 153-198

Goin FJ, Woodburne MO, Zimicz AM, Martin GM, Chornogubsky L (2016) A Brief History of South American Metatherians. Evolutionary Contexts and Intercontinental Dispersals. Springer Earth System Sciences series, Springer, Dordretch, 237 pp

González-Ruiz LR, Góis F, Ciancio MR, Scillato-Yané GJ (2013) Los Peltephilidae (Mammalia, Xenarthra) de la Formación Collón Curá (Colloncurense, Mioceno Medio) Argentina. Rev Bras Paleontol 16(2): 319-330

Hill RV (2005) Integrative morphological data sets for phylogenetic analysis of Amniota: the importance of integumentary characters and increased taxonomic sampling. Syst Biol 54: 530-547

Hill RV (2006) Comparative anatomy and histology of xenarthran osteoderms. J Morphol 267:1441-1460
Holmes WW, Simpson GG (1931) Pleistocene exploration and fossil edentates in Florida. Bull Am Mus Nat His 59: 383-418

Krmpotic CM, Carlini AA, Scillato-Yané GJ (2009a) The species of Eutatus (Mammalia, Xenarthra): assessment, morphology and climate. Quaternary Internatl 210: 66-75

Krmpotic CM, Ciancio MR, Barbeito CG, Mario RC, Carlini AA (2009b) Osteoderm morphology in recent and fossil Euphractinae xenarthrans. Acta Zool 90:339-351

Krmpotic CM, Ciancio MR, Carlini AA, Castro MC, Scarano AC, Barbeito CG (2015) Comparative histology and ontogenetic change in the carapace of armadillos (Mammalia: Dasypodidae). Zoomorphology 134(4): 601-616

Kvadsheim PH, Aarseth JJ (2002) Thermal function of phocid seal fur. Marine Mammal Sci 18(4):952-962

Kvadsheim PH, Folkow LP, Blix AS (1994) A new device for measurement of the thermal conductivity of fur and blubber. J Thermal Biol 19(6): 431-435

Legarreta L, Uliana MA (1994) Asociaciones de fósiles y hiatos en el Supracretácico-Neógeno de Patagonia: una perspectiva estratigráfico-secuencial. Ameghiniana 31:257-281

Liwanag HE, Berta A, Costa DP, Budge SM, Williams TM (2012) Morphological and thermal properties of mammalian insulation: The evolutionary transition to blubber in pinnipeds. Biol J Linn Soc 107(4): 774-787

McNab BK (1980) Energetics and the limits to a temperate distribution in armadillos. J Mammal 61(4):606-627

Meredith RW, Janečka JE, Gatesy J, Ryder OA, Fisher CA, Teeling EC, Goodbla A, Eizirik E, Taiz LLS, Stadler T, Rabosky DL, Honeycutt RL, Flynn JJ, Ingram CM, Steiner C, Williams TL, Robinson TJ, Burk-Herrick A, Westerman M, Ayoub NA, Springer MS, Murphy WJ (2013) Impacts of the Cretaceous Terrestrial Revolution and $\mathrm{KPg}$ extinction on mammal diversification. Science 334(6055): 521-524

Ortiz-Jaureguizar E, Cladera G (2006) Paleoenvironmental evolution of southern South America during the Cenozoic. J Arid Environ 66: 489-532

Pascual R, Odreman Rivas OE (1971) Evolución de las comunidades de vertebrados del Terciario argentino. Los aspectos paleozoogeográficos y paleoclimáticos relacionados. Ameghiniana 8: $372-412$

Pascual R, Ortiz-Jaureguizar E (1990) Evolving climates and mammal faunas in Cenozoic South America. J Hum Evol 19: 23-60

Pascual R, Ortiz-Jaureguizar E, Prado JL (1996) Land-mammals: paradigm for Cenozoic South American geobiotic evolution. In: Arratia G (ed) Contributions of Southern South America to Vertebrate Paleontology. Münchner Geowiss Abh 30(A): 265-319

Porpino KDO, Fernicola JC, Bergqvist LP (2009) A new cingulate (Mammalia: Xenarthra), Pachyarmatherium brasiliense sp. nov., from the late Pleistocene of northeastern Brazil. J Vertebr Paleontol 29(3): 881-893

Rodriguez-Bualó S, Zurita AE, Góis F, Miño-Boilini AR, Soibelzon E (2014) Pampatheriidae (Xenarthra, Cingulata) from Tarija Valley, Bolivia: a taxonomic update. Riv Ital Paleontol S 120 (2): 253-259

Scheyer TM, Sánchez-Villagra MR (2007) Carapace bone histology in the giant pleurodiran turtle Stupendemys geographicus: phylogeny and function. Acta Palaeontol Pol 52(1):137-154

Scillato-Yané GJ (1982) Los Dasypodidae (Mammalia, Edentata) del Plioceno y Pleistoceno de Argentina. Doctoral Thesis (unpublished), Facultad de Ciencias Naturales y Museo, UNLP

Scillato-Yané GJ, Krmpotic CM, Esteban GI (2010) Las especies del género Chasicotatus Scillato-Yané (Eutatini, Dasypodidae). Rev Mex Cs Geol 27(1): 43-55

Soibelzon E, Avilla LS, Castro M (2015) The cingulates (Mammalia: Xenarthra) from the late Quaternary of northern Brazil: fossil records, paleoclimates and displacements in America. Quaternary Internatl 377: 118-125 
Soibelzon E, León DC (2017) Effects of climatic oscillations on the faunas. The Holocene Thermal Maximum and the displacement of armadillos in Argentina: anatomical features and conservation. J Arch Sci Reports 11: 90-98

Soibelzon E, Medina M, Abba AM (2013) Late Holocene armadillos (Mammalia, Dasypodidae) of the sierras of Córdoba, Argentina: Zooarchaeology, diagnostic characters and their paleozoological relevance. Quaternary Internatl 299: 72-79

Soibelzon E, Miño-Boilini AR, Zurita AE, Krmpotic CM (2010) Los Xenarthra (Mammalia) del Ensenadense (Pleistoceno Inferior a Medio) de la Región Pampeana (Argentina). Rev Mex Cs Geol 27: 449-469

Soibelzon E, Zurita AE, Carlini AA (2006) Glyptodon munizi Ameghino (Mammalia, Cingulata, Glyptodontidae): redescripción y anatomía. Ameghiniana 43: 377-384

Vickaryous MK, Hall BK (2006) Osteoderm morphology and development in the nine-banded armadillo, Dasypus novemcinctus (Mammalia, Xenarthra, Cingulata). J Morphol 267(11):1273-1283

Vickaryous MK, Sire JY (2009) The integumentary skeleton of tetrapods: origin, evolution, and development. J Anat 214(4):441-464

Vizcaíno SF (1994a) Sistemática y anatomía de los Astegotheriini Ameghino, 1906 (nuevo rango) (Xenarthra, Dasypodidae, Dasypodinae). Ameghiniana 31(1): 3-13

Vizcaíno SF (1994b) Mecánica masticatoria de Stegotherium tessellatum Ameghino (Mammalia, Xenarthra) del Mioceno de Santa Cruz
(Argentina). Algunos aspectos paleoecológicos relacionados. Ameghiniana 31: 283-290

Vucetich MG, Verzi DH (1991) Un nuevo Echimydae (Rodentia, Histricognathi) de la Edad Colhuehuapense de Patagonia y consideraciones sobre la sistemática de la familia. Ameghiniana 28(1-2): 67-74

Witmer LM (1995) The extant phylogenetic bracket and the importance of reconstructing soft tissues in fossils. In: Thomason $\mathrm{J}$ (ed) Functional Morphology in Vertebrate Paleontology. Cambridge University Press, Cambridge, pp 19-33

Wolf D, Kalthoff DC, Sander PM (2012) Osteoderm histology of the Pampatheriidae (Cingulata, Xenarthra, Mammalia): implications for systematics, osteoderm growth, and biomechanical adaptation. J Morphol 273(4):388-404

Zachos JC, Stott LD, Lohmann KC (1994) Evolution of early Cenozoic marine temperatures. Paleoceanography 9(2): 353-387

Zachos J, Pagani M, Sloan L, Thomas E, Billups K (2001) Trends, rhythms, and aberrations in global climate 65 ma to present. Science 292: 686-693

Zurita AE, González Ruiz LR, Gómez-Cruz AJ, Arenas-Mosquera JE (2013) The most complete known Neogene Glyptodontidae (Mammalia, Xenarthra, Cingulata) from northern South America: taxonomic, paleobiogeographic, and phylogenetic implications. J Vertebr Paleontol 33: 696-708 